HortSCIENCE 27(5):412-413. 1992.

\title{
Additional East European Pyrus Germplasm with Resistance to Pear Psylla Nymphal Feeding
}

\author{
R.L. Bell \\ U.S. Department of Agriculture, Agricultural Research Service, \\ Appalachian Fruit Research Station, 45 Wiltshire Road, Kearneysville, \\ WV 25430-9802
}

Additional index words. pear, Insecta, Homoptera, Cacopsylla pyricola, Psylla, plant genetic resources, antixenosis

\begin{abstract}
Eight cultivars and wild seedlings of pear (Pyrus spp.) from Eastern Europe were evaluated for resistance to feeding by early instar pear psylla [Cacopsylla pyricola (Foerster)] in a 24-hour assay. All were compared to a susceptible control, 'Bartlett' $(P$. communis L.), and to a moderately resistant control, NY10352 (P. communis $\times P$.

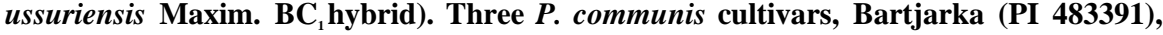
Lucele (PI 483402), and Kajzerka (PI 506387), and a wild seedling (PI 506381) of undetermined species, exhibited a high degree of host resistance, measured as reduced frequency of feeding and increased either mortality or movement off of the plants.
\end{abstract}

Cultivars of pear with resistance to the pear psylla would significantly reduce production costs associated with control of this major arthropod pest. All major cultivars grown in Europe and North America are highly susceptible. Host resistance to the pear psylla has recently been reported in a collection of East European pear germplasm (Bell and Stuart, 1990). Eleven of 59 cultivars and wild seedlings assayed exhibited a high level of nymphal feeding antixenosis, observed as inhibition of feeding, which is thought to lead directly to nymphal mortality and delayed development (Butt et al., 1989). This mode of resistance, combined with ovipo-

Received for publication 22 Aug. 1991. Accepted for publication 9 Dec. 1991. I acknowledge the technical support of Suzanne Luca, Teresa Shatzer, and Wayne Zook. The cost of publishing this paper was defrayed in part by the payment of page charges. Under postal regulations, this paper therefore must be hereby marked advertisement solely to indicate this fact. sitional antixenosis, i.e., inhibition of egglaying, may provide economic supression of psylla populations.

The pear germplasm in the East European collection is diverse in fruit and tree characteristics (van der Zwet et al., 1987, 1989; R.L.B., unpublished). Although most of the resistant cultivars are $P$. communis L., the species to which all major cultivars grown in Europe and North America belong, their fruit quality is too poor to warrant commercial production in this country. They are valuable as parents in a breeding program, the success of which will depend, in part, on the diversity for all characteristics of economic importance. Therefore, additional germplasm is being evaluated to broaden the genetic base for selection, and to complete the documentation of resistance in this East European pear collection. This report contains the results of the evaluation of additional pear germplasm from Eastern Europe that was not available for the earlier study (Bell and Stuart, 1990). 
Table 1. Mean number of live and feeding pear psylla nymphs on eight plant introductions of pear from Eastern Europe, a susceptible control ('Bartlett'), and a resistant control (NY10352). ${ }^{\text {z }}$

\begin{tabular}{lllll}
\hline \hline & & & \multicolumn{2}{c}{ Nymphs (no.) $^{\mathbf{x}}$} \\
\cline { 4 - 5 } P.I. no. & Germplasm & Species & $17.2 \mathrm{a}$ & $17.8 \mathrm{a}$ \\
\hline-- & Bartlett & communis & $12.5 \mathrm{~b}$ & $15.0 \mathrm{ab}$ \\
483379 & Prague No. 1 & communis & $11.8 \mathrm{~b}$ & $15.4 \mathrm{ab}$ \\
483373 & Kalcbasa Plocka & communis & $10.6 \mathrm{~b}$ & $12.6 \mathrm{bc}$ \\
483403 & Aniversarea & communis & $10.4 \mathrm{~b}$ & $13.2 \mathrm{bc}$ \\
483401 & Crna Polska & communis & $4.6 \mathrm{c}$ & $9.6 \mathrm{cde}$ \\
-- & NY10352 & communis $\times$ ussuriensis & $2.0 \mathrm{~cd}$ & $10.0 \mathrm{~cd}$ \\
483402 & Lucele & communis & $1.0 \mathrm{~d}$ & $9.5 \mathrm{cde}$ \\
483391 & Batjarka & communis & $0.2 \mathrm{~d}$ & $7.0 \mathrm{de}$ \\
506381 & -- & Unverified & $0.0 \mathrm{~d}$ & $5.8 \mathrm{e}$ \\
506387 & Kajzerka & communis &
\end{tabular}

${ }^{x}$ Mean separation within columns by Waller-Duncan $k$-ratio $t$ test, with $k$-ratio of $100(\alpha=0.05)$.

'Most likely species, based on collector's notes and preliminary observations by the author.

'Mean of five single-plant replicates, 20 nymphs per plant.

Germplasm, bioassay, and experimental design. Eight accessions of pear germplasm released from plant quarantine since 1978 were assayed. Brief descriptions of some clones were published previously (van der Zwet et al. 1987, 1989). Trees of the accessions and controls were produced by budding onto 'Bartlett' seedling rootstock. The trees were grown in a greenhouse until used in laboratory assays. Actively growing budded trees, $\approx 30$ to $50 \mathrm{~cm}$ high, were used. All but the uppermost four fully expanded leaves were removed immediately before infestation. First or second instar pear psylla nymphs, hatched or molted within $48 \mathrm{~h}$, were obtained from a laboratory colony maintained on 'Bartlett' seedling rootstock. Colonies were founded in May 1990 and 1991 from fieldcollected adults, and new colonies were started at 2-month intervals in 1990. Therefore, the nymphs were no older than first or second generation laboratory-reared cohorts. Four feeding trials were completed in 1990, and a fifth was completed in 1991.

The feeding antixenosis bioassay procedure differed from that of the previous study (Bell and Stuart, 1990) in the method of infestation. Ten nymphs were transferred to 1$\mathrm{cm}^{2}$ leaf sections and attached to each of the top two fully expanded leaves. The trees were then kept in a laboratory growth room at 25 $\pm 1 \mathrm{C}$ and a $16 / 8 \mathrm{~h}$ (L/D) photoperiod under cool-white fluorescent bulbs. Within $6 \mathrm{~h}$, all nymphs had moved onto the plant. At $24 \mathrm{~h}$, the number of actively feeding nymphs and the total number of live nymphs on the plants were recorded. Active feeding was indicated by the presence of excreted honeydew droplets. The design was a randomized complete block in which five independent trials (i.e., blocks) consisted of single trees of each accession, plus single trees of a susceptible control ('Bartlett') and a moderately resistant control, NY10352 (P. communis $\times$ P. ussuriensis Maxim. $\mathrm{BC}_{1}$ hybrid).

Data analysis. The total number of nymphs feeding on each plant was analyzed as the principal measure of antixenosis. Homogeneity of variance was confirmed by Bartlett's test. Normality of residual error was tested by the Shapiro-Wilk statistic W. Data transformation was found to be unnecessary. A mixed model was assumed, in which the effects of replications were random and accession effects were fixed. The WallerDuncan $k$ - ratio test was used to test for differences among accession means and the controls (SAS Institute, Inc., 1987).

Results. Variation among accessions was significant for total feeding $(P=0.0001)$ and total found alive $(P=0.0001)$. No significant differences were found among replications for either variable. Mean number feeding varied from 17.2 for 'Bartlett' to 0.0 for 'Kajzerka'. The frequency distribution of accessions for mean number feeding was similar to the bimodality shown in the earlier study done on the group of 59 accessions (Bell and Stuart, 1990). Feeding on all genotypes was significantly less than on 'Bartlett' (Table 1). However, Prague No. 1, 'Kalebasa Plocka', 'Aniversarea', and 'Crna Polska' were more susceptible than NY10352. 'Lucele' was not significantly more resistant than NY10352, but 'Batjarka', 'Kajzerka', and PI 506381 were significantly more resistant than NY10352. The named accessions are apparently $P$. communis cultivars, and were collected in Yugoslavia (van der Zwet et al., 1987). The species identity of PI 506381 is unconfirmed but is thought by the collector to be a hybrid of $P$. communis with $P$. nivalis Jacq. (van der Zwet et al., 1989); it is similar in morphology to PI 506382, previously identified as resistant to nymphal feeding (Bell and Stuart, 1990).

All genotypes also harbored significantly fewer live nymphs than 'Bartlett' and were equal to or numerically lower than NY10352 in this respect. This characteristic is another measure of antixenosis, as nymphs that do not find the plant to be a suitable host and commence feeding either die or migrate off the plant (Butt et al., 1988).

This study completes the evaluation of nymphal feeding antixenosis in the East European pear germplasm thus far released from plant quarantine. Fifteen of 67 accessions, or nearly $21 \%$ of the introductions, have been identified as moderately to highly resistant. Of these, 11 are apparently $P$. communis. This East European Pyrus germplasm will be useful for the development of cultivars with host resistance to the pear psylla, one of the most important arthropod pests of pear in Europe and North America.

\section{Literature Cited}

Bell, R.L. and L.C. Stuart. 1990. Resistance in Eastern European Pyrus germplasm to pear psylla nymphal feeding. HortScience 25:789-791.

Butt, B.A., L.C. Stuart, and R.L. Bell. 1988. Feeding behavior of pear psylla (Homoptera:Psyllidae) nymphs on susceptible and resistant Pyrus germplasm. J. Econ. Entomol. 81:1394-1397.

Butt, B.A., L.C. Stuart, and R.L. Bell. 1989. Feeding, longevity, and development of pear psylla (Homoptera:Psyllidae) nymphs on resistant and susceptible pear genotypes. J. Econ. Entomol. 82:458-461.

SAS Institute, Inc. 1987. SAS/STAT guide for personal computers, version 6 edition. SAS Institute, Inc. Cary, N.C.

van der Zwet, T., V. Cociu, B. Czamecki, J. Nyeki, and J. Blazek. 1989. Collecting Pyrus germplasm in Romania, Poland, Hungary, and Czechoslovakia. HortScience 24:420-424.

van der Zwet, T., D. Stankovic, and B. Ristevski. 1987. Collecting Pyrus germplasm in Yugoslavia. HortScience 22:15-21. 